\title{
PHENOTYPIC AND GENETIC CORRELATIONS OF MILK AND TYPE TRAITS OF HOLSTEIN-FRIESIAN BULL DAMS
}

\author{
V. Pantelić ${ }^{*}$ D. Nikšić, D. Ostojić-Andrić, Ž. Novaković, D. Ružić- \\ Muslić, N. Maksimović, M. Lazarević \\ Institute for Animal Husbandry, Belgrade-Zemun, 11080 Zemun \\ * Corresponding author:Vlada Pantelić, e-mail: vladap4@gmail.com \\ Original scientific paper
}

\begin{abstract}
The study of the production capacities of cattleaimed at increase of the capacity of cattle to produce milk, milk fat and calves, greatly depends on pehotypic anf genetic variability, heritability and correlation between preferable traits, as well as level of production in the population. Objective of the study was to calculate the variability, phenotypic and genetic correlation of milk and type traits by applying the method of linear scoring of cows in the nucleus herd of Holstein-Friesian bull dams and also to determine their significance in cattle selection. For all studied traits, main variation-statistical parameters were calculated by applying method of least squares: arithmetic mean, standard deviation, variation coefficient, standard error and variation interval. Negative phenotypic correlations between production of milk and type traits ranged from -0.12 (rear leg set, side view) to -0.01 (rump height and body depth) and positive from 0.03 (rear teat placement) to 0.23 (suspensory ligament). Phenotypic correlations between milk fat percentage and type traits varied in the range from -0.08 (fore teat placement) to 0.14 (rump height). Negative genetic correlations between milk production and type traits ranged from -0.11 (rear udder height) to -0.01 (rump width and dairy form), and positive from 0.03 (rear legs set, rear view) to 0.23 (suspensory ligament). Genetic correlations between the percentage of milk fat and type traits ranged from -0.15 (pelvic position) to 0.18 (rump height). Information about phenotypic and genetic correlations between milk and type traits can be of multiple significance in cow selection since it offers possibility to select heads of cattle for multiple traits at the same time.
\end{abstract}

Key words: correlations, milk performance, type traits, bull dams. 


\section{Introduction}

Genetic correlations are very significant in direct or indirect selection where changes in one trait are induced by selection for another trait between which the genetic correlation exists.

Phenotypic correlation between milk and fertility traits is very significant for simulatanous selection for multiple traits, and even more significant for indirect selection in conditions when some traits cannot be improved directly. At the same time, the potential success of selection is increased by reaching early selection conclusions and decisions.

Linear type traits are basis of all modern classification systems, and represent foundation of all systems used for description of dairy cow. Linear classification is based on measuring/measurements of individual type traits rather than giving opinions on them. It describes the level of presence of certain trait, and not the level of desirability (Pantelić et al.2011).

Body development and type are very important parameters of production capacity of cow, their potential to consume sufficient amounts of food, produce technologicaly high quality milk, reduce the consumption of energy in production and remain in production as long as possible giving as many progeny as possible (Pantelić et al.2009).

Stojić et al.(2002) state that 14 traits, of which 6 are body development traits and 8 uder traits, are included in linear type scoring of the Black and White cattle. Average expression/presence of certain traits is scored with mark 5. For following 4 traits: pelvic position and rear legs set, udder balance and teat size, this is the prefereable score. For other traits, higher scores are preferable.

Average values of type scores determined for Holstein-Friesian bull dams by Pantelić et al. $(2010 a$ ) were following : body height 7.11 , strength and capacity 7.34 , dairy form 7.23 , rump width 6.31 , pelvic position 5.29 , rear legs set 5.10 , fore udder attachment 6.69 , rear udder height 6.95 , rear uder width 7.31 , udder depth 6.70 , suspensory ligament 6.85 , udder blance 5.17 , teat placement 5.96 , teat length 5.23 .

In the study of the heritability of type traits of first calving Black and White heifers, Pantelic et al.(2010b), established average values of body development scores obtained by using the method of Least squares in the range from 5.29 (rear legs set) to 7.06 (dairy form). Score for pelvic position was very close to the preferable score (5) - 5.37. Udder scores ranged from 4.91 (teat length) to 6.92 (rear udder width). Udder balance was scored in average - 5.05, and suspensory ligament 6.35 . 
Živanović (2002) studied the variability of linear type scores and milk traits in first calving Black and White heifers on 2.976 cows. Negative genetic correlations between milk traits and linear type scores ranged from $-0,241$ to 0,856 , for many studied traits. Positive genetic correlations ranged from 0,544 to 0,744 .

In the analysis of production and body traits of Holstein cows, Koenen and Groen (1998) determined the strength of genetic and phenotypic correlations between type and conformation traits. Values of phenotypic correlation coefficients ranged between -0.28 (udder depth and body depth) and 0.95 (body size and rump height), and genetic correlation coefficients between -0.49 (body depth and udder depth) and 0.77 (body mass and chest girth).

Genetic correlation between conformation traits, calculated on a sample of 58864 Black and White cows, ranged from -0.52 (score for legs and hoofs and front legs set, side view) to 0.85 (score for udder and front teat placement), as stated by Vollema and Groen (1997).

\section{Material and methods}

For production of bulls of Holstein-Friesian breed, it is necessary to select the best cows from the main population. Bull dams, as a rule, represent approx. 1\% of best cows of the population under control, primarily in regard to the production of milk and milk fat, but also in regard to body development, udder and fertility traits (Pantelić, 2004.).

Bull dams are selected according to criteria determined by the breeding program, usually on big dairy farms (but also on developed family holdings).

Linear type and body development scoring of breeding animals is carried out according to determined criteria, individually or on selection inspections/exhibitions, by direct inspection of the animal's appearance and condition. It is preferable to score cows in the first lactation in the period 30-105 day from calving, because of the activity and capacity of udder during this period and assumption that the genetic basis is more reliable for scoring in this period, and the influence of the environmental factors lower (Pantelić et al.2007). Even though linear scores are not used to describe the desirability of certain trait, score 9 will represent either the most preferable score or less preferable of two extremes.

Study included 127 cows of Holstein-Friesian breed, selected into the category of bull dams on farms of PKB Corporation. Selection of bull dams was carried out by a team consisting of three members, representatives of regional and primary breeding organizations, and livestock-veterinary center. Selection of cows for the bull dam herd was carried out after the first concluded lactation, i.e. based on subsequent lactations. 
The variability of milk traits was calculated for all studied bull dams, as follows: PM-production of milk (milk yield); MF kg-production of milk fat in kilograms (milk fat yield); MF\%-milk fat content.

The cows' exterior was measured and following traits scored linearly: RHrump height; CW-chest width; BD-body depth; PP-pelvic position; RW-rump width; DF-dairy form; RLSRV-rear legs set, rear view; RLSSV-rear legs set, side view; HA-hoof angle; FUA-front udder attachment; FTP-front teat placement; TLteat length; UD-udder depth; RUH-rear udder height; SL-suspensory ligament; RTP-rear teat placement.

Basic variation-statistical parameters were calculated for studied type and milk traits: arithmetic mean $(\bar{X})$, standard deviation (SD), variation coefficients $(\mathrm{CV})$, standard mean error ( $\bar{X} \bar{X})$, variation interval (Min-Max).

Results of the study of phenotypic and genetic correlations, variability of production traits and linear type scores were obtained using the following model:

$\mathrm{Y}_{\mathrm{ijkl}}=\mu+\mathrm{O}_{\mathrm{i}}+\mathrm{F}_{\mathrm{j}}+\mathrm{L}_{\mathrm{k}}+\mathrm{e}_{\mathrm{ijkl}}$

$\mathrm{Y}_{\mathrm{ijk}}=$ phenotypic value of traits included in the analysis

$\mu=$ general mean value

$\mathrm{O}_{\mathrm{i}}=$ fixed effect of the $i$ bull sire

$\mathrm{F}_{\mathrm{j}}=$ fixed effect of the $j$ farm

$\mathrm{L}_{\mathrm{k}}=$ fixed effect of the $k$ order of lactation

$\mathrm{e}_{\mathrm{ijklm}}=$ random error (other uncontrolled effects)

\section{Results and Discussion}

In order to realize genetic progress in the nucleus herd, it is necessary to have very detailed, precise and reliable main records on all heads comprising the nucleus herd, genetic evaluations of the traits relvant for realization of breeding program, as well as rank of breeding animals used as parents of future generations. However, in case of absence of adequate dissemination of genetic progress from nucleus herd to the remaining population, all efforts made towards the improvement of certain traits and realization of set breeding program can be without success (Harris and Newman, 1994).

Table 1 shows average values and variability of milk traits and linear type scores established in bull dams of Holstein-Friesian breed. 
Table 1. Average values and variability of milk traits and linear type scores in Holstein-Friesian bull dams

\begin{tabular}{|l|c|c|c|c|c|c|c|}
\hline & $\mathrm{n}$ & $\bar{x}$ & $S_{\bar{x}}$ & $\mathrm{SD}$ & $\mathrm{Cv}$ & Min. & Max. \\
\hline PM,kg & 127 & 10245,98 & 136,72 & 1540,83 & 15,03 & 6514 & 13251 \\
\hline MF, \% & 127 & 3,53 & 0,01 & 0,18 & 5,27 & 2,80 & 3,89 \\
\hline MF, kg & 127 & 361,95 & 5,03 & 56,78 & 15,68 & 225,40 & 485,51 \\
\hline RH & 127 & 5,40 & 0,11 & 1,33 & 24,71 & 3,000 & 8,00 \\
\hline CW & 127 & 7,09 & 0,06 & 0,74 & 10,52 & 4,000 & 8,00 \\
\hline BD & 127 & 7,38 & 0,05 & 0,60 & 8,17 & 6,000 & 9,00 \\
\hline PP & 127 & 5,39 & 0,05 & 0,57 & 10,73 & 4,000 & 7,00 \\
\hline RW & 127 & 6,55 & 0,07 & 0,88 & 13,55 & 4,000 & 9,00 \\
\hline DF & 127 & 7,35 & 0,04 & 0,51 & 6,96 & 6,000 & 8,00 \\
\hline RLSRV & 127 & 5,22 & 0,09 & 1,03 & 19,88 & 3,000 & 8,00 \\
\hline RLSSV & 127 & 5,28 & 0,05 & 0,66 & 12,56 & 4,000 & 7,00 \\
\hline HA & 127 & 5,27 & 0,08 & 1,00 & 19,05 & 3,000 & 7,00 \\
\hline FUA & 127 & 6,65 & 0,07 & 0,86 & 13,03 & 5,000 & 8,00 \\
\hline FTP & 127 & 5,43 & 0,09 & 1,05 & 19,36 & 3,000 & 8,00 \\
\hline TL & 127 & 4,76 & 0,07 & 0,82 & 17,31 & 2,000 & 7,00 \\
\hline UD & 127 & 6,96 & 0,07 & 0,81 & 11,64 & 4,000 & 8,00 \\
\hline RUH & 127 & 7,13 & 0,05 & 0,61 & 8,66 & 5,000 & 8,00 \\
\hline SL & 127 & 7,08 & 0,06 & 0,78 & 11,05 & 5,000 & 8,00 \\
\hline RTP & 127 & 5,89 & 0,10 & 1,13 & 19,27 & 4,000 & 8,00 \\
\hline
\end{tabular}

Bull dams of Holstein-Friesian breed realized average milk yield of $10245.98 \mathrm{~kg}$, with variation interval in range from $6514 \mathrm{~kg}$ to $13251 \mathrm{~kg}$. Average milk fat yield was $361.95 \mathrm{~kg}$, and milk fat content $3,53 \%$.

Average values of linear type scores obtained by method of Least squares in present study ranged from 4.76 (teat length) to 7.38 (body depth). Score for the pelvic position was very close to the preferable score (5) - 5.39. Scores for the rear legs set, side and rear view were very similar (5.22 and 5.28), and very close to the preferable score given for the right position. Udder scores ranged from 5.43 (front teat placement) to 7.13 (rear udder height). Rear teat placement was scored in average with mark 5.89, udder depth with 6.96, and suspensory ligament with 7.08.

By comparing linear type scores with similar studies by other authors, certain difficulties arise due to different evaluation/scoring systems used, different traits being scored, as well as different breeds. If linear type scores, regardless of the Pscoring scale used, are compared with results obtained by other authors, it can be concluded that present results are very similar to results stated by Pantelic et al. (2010a).

The knowledge of the phenotypic and genetic correlations between milk and body development traits and type traits is very important in selection work, 
where in addition to high production, also good health and longevity of animals in herd are expected.

The genetic correlations can be positive, when changes in the additive gene effect in one trait lead to change of the additive gene effect of the same direction in another trait. The negative genetic correlation indicates opposite direction of changes in additive gene effects in two traits. Increase of aditive gene effect in one trait is followed by decrease of mentioned effect in the other trait, and vice versa.

The genetic (bellow the diagonal) and phenotypic (above the diagonal) correlations of milk traits and linear type scores of bull dams are presented in Table 2 .

Table 2. The genetic (bellow the diagonal) and phenotypic (above the diagonal) correlations of milk traits and linear type scores of bull dams

\begin{tabular}{|c|c|c|c|c|c|c|c|c|c|c|c|c|c|c|c|c|c|c|c|}
\hline & 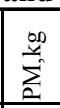 & $\begin{array}{l}\circ \\
\sum \\
\Sigma\end{array}$ & $\begin{array}{l}\frac{10}{3} \\
\sum^{n} \\
\Sigma\end{array}$ & 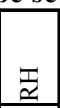 & z & 官 & $\stackrel{a}{a}$ & ב) & 告 & $\begin{array}{l}\vec{z} \\
\tilde{\Delta} \\
\underline{\underline{z}}\end{array}$ & $\mid \begin{array}{l}\vec{z} \\
\tilde{n} \\
\hat{1} \\
\underline{\underline{x}}\end{array}$ & 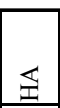 & 志 & 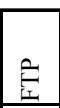 & $\vec{\theta}$ & $\rho$ & 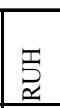 & $\ddot{n}$ & 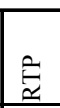 \\
\hline $\mathrm{PM}, \mathrm{kg}$ & & $-0,02$ & 0,94 & $-0,01$ & 0,08 & $-0,01$ & \begin{tabular}{|l|l|}
0,09 \\
\end{tabular} & $-0,11$ & $-0,05$ & 0,05 & $-0,12$ & 0,08 & $-0,10$ & 0,07 & $-0,09$ & $-0,05$ & $-0,05$ & \begin{tabular}{|l|}
0,23 \\
\end{tabular} & 0,03 \\
\hline MF, & 28 & & 0,30 & 0,14 & $-0,02$ & 0,06 & $-0,03$ & 0,05 & 0,01 & 0,13 & $-0,04$ & 0,12 & 0,08 & $-0,08$ & 0,04 & 0,06 & 0,02 & $-0,02$ & 0,00 \\
\hline $\mathrm{MF}, 1$ & & 0,12 & & 0,04 & 0,07 & 0,02 & \begin{tabular}{|l|}
0,08 \\
\end{tabular} & $-0,08$ & $-0,04$ & \begin{tabular}{|l|}
0,09 \\
\end{tabular} & $-0,13$ & 0,12 & $-0,07$ & 0,05 & $-0,07$ & $-0,03$ & $-0,04$ & 0,22 & 0,04 \\
\hline $\mathrm{H}$ & 2 &, 18 & 0,17 & & 0,26 &, 30 & \begin{tabular}{|l|l|}
0,04 \\
\end{tabular} & \begin{tabular}{|l|l}
0,01 \\
\end{tabular} & \begin{tabular}{|l|l}
0,45 \\
\end{tabular} & \begin{tabular}{|l|}
0,35 \\
\end{tabular} & $-0,21$ & \begin{tabular}{|l|l}
0,38 \\
\end{tabular} & \begin{tabular}{|l|l}
0,48 \\
\end{tabular} & \begin{tabular}{|l}
0,33 \\
\end{tabular} & \begin{tabular}{|l|l}
0,00 \\
\end{tabular} & \begin{tabular}{|l}
0,11 \\
\end{tabular} & \begin{tabular}{|l}
0,08 \\
\end{tabular} & 0,18 & \begin{tabular}{|l}
0,40 \\
\end{tabular} \\
\hline $\mathrm{CW}$ & 2 & 0,03 &, 12 & 0,26 & & 0,30 & 0,11 & 0,20 & 0,09 & \begin{tabular}{|l|}
0,16 \\
\end{tabular} & $-0,05$ & \begin{tabular}{|l|l|}
0,18 \\
\end{tabular} & 0,08 & 0,19 & 0,11 & 0,22 & $-0,13$ & 0,10 & 0,18 \\
\hline $\mathrm{BD}$ & 5 & 0,10 &, 07 & 0,30 & 0,30 & & $-0,08$ & 0,22 & 0,36 & 0,22 & $-0,10$ & \begin{tabular}{|l|l|}
0,22 \\
\end{tabular} & \begin{tabular}{|l|}
0,31 \\
\end{tabular} & \begin{tabular}{|l}
0,03 \\
\end{tabular} & 0,19 & 0,16 & \begin{tabular}{|l}
0,11 \\
\end{tabular} & 0,12 & \begin{tabular}{|l}
0,14 \\
\end{tabular} \\
\hline PI & 14 & $-0,15$ & 0,09 & 0,09 & 0,07 & $-0,09$ & & 0,15 & 0,04 & $-0,28$ & 0,20 & $-0,21$ & $-0,19$ & $-0,09$ & $-0,15$ & 0,07 & $-0,05$ & $-0,09$ & $-0,12$ \\
\hline $\mathrm{RV}$ & 01 & 0,06 & 0,02 & $-0,03$ & 0,16 & 0,18 & 0,13 & & 0,06 & 0,08 & 0,12 & \begin{tabular}{|l|l}
0,07 \\
\end{tabular} & $-0,02$ & $-0,04$ & 0,02 & 0,01 & 0,03 & 0,09 & $-0,14$ \\
\hline DF & $-0,01$ & $-0,13$ & $-0,04$ & 0,48 & 0,12 & 0,36 & \begin{tabular}{|l|l|}
0,03 \\
\end{tabular} & 0,05 & & 0,25 & $-0,17$ & 0,12 & 0,48 & 0,13 & 0,02 & 0,17 & 0,26 & 0,15 & 0,26 \\
\hline $\mathrm{SI}$ & 0,03 & 0,16 & 0,07 & 0,34 & 0,21 & 0,23 & $-0,23$ & 0,11 & 0,25 & & $-0,64$ & 0,73 & 0,31 & 0,26 & 0,05 & 0,06 & 0,04 & 0,13 & 0,30 \\
\hline RLSS & 0,08 & $-0,09$ & 0,10 & 0,27 & $-0,07$ & $-0,14$ & 0,17 & 0,06 & $-0,21$ & $-0,63$ & & $-0,55$ & $-0,29$ & $-0,23$ & $-0,08$ & $-0,04$ & $-0,10$ & $-0,06$ & $-0,29$ \\
\hline & 0,09 & 0,15 & 0,13 & 0,62 & 0,21 & 0,23 & $-0,18$ & 0,08 & 0,11 & \begin{tabular}{|l|}
0,69 \\
\end{tabular} & $-0,59$ & & 0,32 & 0,25 & 0,14 & 0,11 & $-0,03$ & 0,04 & 0,30 \\
\hline$\overline{\mathrm{FUA}}$ & $-0,04$ & 0,03 & 0,02 & 0,49 & 0,14 & 0,31 & $-0,23$ & $-0,02$ & 0,46 & 0,35 & $-0,31$ & 0,37 & & 0,22 & 0,06 & 0,30 & 0,16 & 0,08 & 0,47 \\
\hline FTP & 0,10 & 0,07 & 0,11 & 0,32 & 0,15 & 0,02 & $-0,05$ & $-0,04$ & 0,19 & 0,27 & $-0,22$ & 0,25 & 0,25 & & $-0,02$ & 0,12 & $-0,10$ & 0,13 & 0,75 \\
\hline TL & 0,09 & 0,06 & 0,06 & 0,00 & 0,09 & 0,21 & $-0,19$ & 0,00 & \begin{tabular}{|l|l|}
0,03 \\
\end{tabular} & 0,09 & $-0,07$ & 0,19 & 0,08 & $-0,02$ & & $-0,11$ & 0,03 & \begin{tabular}{|l|}
0,24 \\
\end{tabular} & 0,00 \\
\hline UD & $-0,06$ & 0,03 & $-0,05$ & 0,08 & 0,17 & 0,18 & 0,06 & 0,02 & \begin{tabular}{|l|l|}
0,15 \\
\end{tabular} & 0,05 & $-0,04$ & 0,09 & 0,31 & 0,13 & $-0,11$ & & $-0,02$ & \begin{tabular}{|l|}
0,03 \\
\end{tabular} & 0,22 \\
\hline RUH & $-0,11$ & $-0,07$ & $-0,12$ & \begin{tabular}{|l|}
0,15 \\
\end{tabular} & $-0,15$ & 0,14 & $-0,08$ & \begin{tabular}{|l|}
0,08 \\
\end{tabular} & 0,26 & \begin{tabular}{|l|}
0,08 \\
\end{tabular} & $-0,09$ & 0,00 & 0,16 & $-0,07$ & 0,03 & $-0,08$ & & \begin{tabular}{|l|}
0,16 \\
\end{tabular} & $-0,05$ \\
\hline SL & 0,23 & 0,02 & 0,23 & 0,18 & 0,02 & 0,13 & $-0,08$ & 0,10 & 0,19 & 0,12 & $-0,04$ & \begin{tabular}{|l|l|}
0,02 \\
\end{tabular} & 0,15 & 0,11 & 0,21 & 0,00 & \begin{tabular}{|l}
0,17 \\
\end{tabular} & & 0,13 \\
\hline $\begin{array}{l}\text { RTP } \\
\end{array}$ & 0,07 & 0,08 & \begin{tabular}{|l|}
0,09 \\
\end{tabular} & \begin{tabular}{|l|}
0,38 \\
\end{tabular} & 0,16 & 0,13 & $-0,10$ & $-0,14$ & 0,28 & \begin{tabular}{|l|}
0,31 \\
\end{tabular} & $-0,29$ & \begin{tabular}{|l|}
0,31 \\
\end{tabular} & 0,48 & 0,75 & 0,01 & 0,22 & $-0,05$ & 0,13 & \\
\hline
\end{tabular}

The negative phenotypic correlations between milk production and type traits ranged from -0.12 (rear legs set, side view) to -0.01 (rump height and body depth), and positive from 0.03 (rear teat placement) to 0.23 (suspensory ligament). The phenotypic correlations between milk fat percentage and type traits were in the range from -0.08 (front teat placement) to 0.14 (rump height).

The negative genetic correlations between milk production and type traits ranged from -0.11 (rear udder height) to -0.01 (rump width and dairy form), and the positive correlations from 0.03 (rear legs set, rear view) to 0.23 (syspensory ligament). The genetic correlations between the milk fat percentage and type traits ranged from -0.15 (pelvic position) to 0.18 (rump height).

Determination of the level of correlation between two or multiple traits depends greatly on the level of their expression. The knowledge of phenotypic and 
genetic correlations between body traits can help in defining of the breeding goal, but also in harmonizing the scoring criteria. Although the phenotypic and genetic correlations between body development and type traits and milk traits show different levels of variation, they should be considered in final evaluation of the breeding value of head of cattle, in order to achieve comprehesive selection programs.

\section{Conclusion}

The study shows that values obtained for linear type scores should be included in total evaluation of the breeding value of head of cattle, which will lead to gaining of comprehensive insight into genetic superiority, especially in case of breeding bulls. By using the semen of bulls superior in transfer of genes of preferable traits in the broad population will result in fast achieving of a herd comprising animals uniform in regard to the type, of good conformation, health condition and longevity, which could ber achieved by applying the system of corrective matings.

The phenotypic correlation between traits in cattle breeding relates to presence of common positive or negative covariance, ocuring as the result of the effect of genetic and environment factors.

The genetic correlations are very important in direct or indirect selection where changes in one trait, through selection, can induce changes in other traits between which the genetic correlation exists. This is especially current in view of use of modern methods of mathematical statistics in the evaluation of additive gene value of bulls and cows. In addition, the early selection of parents based on the first lactation will become possible, which will considerably shorten the time necessary for bulls to be introduced into the breeding.

\section{Acknowledgment}

This work was financed by the Ministry of Education and Science, Republic of Serbia, project TR 31053. 


\title{
Fenotipske i genetske korelacije osobina mlečnosti i tipa bikovskih majki holštajn frizijske rase
}

\author{
V. Pantelić, D. Nikšić, D. Ostojić-Andrić, Ž. Novaković, D. Ružić-Muslić, N. \\ Maksimović, M. Lazarević
}

\section{Rezime}

Ispitivanje proizvodnih kapaciteta goveda u cilju povećanja proizvodnje mleka, mlečne masti i broja teladi, u velikoj meri zavisi od fenotipske i genetske varijabilnosti, heritabiliteta i povezanosti poželjnih osobina, kao i nivoa proizvodnje u populaciji.

Cilj ovih istraživanja bio je da se u nukleus zapatu bikovskih majki holštajn frizijske rase primenom linearnog metoda ocenjivanja krava izračuna varijabilnost, fenotipska i genetska povezanost osobina mlečnosti i tipa, i njihov značaj u selekciji goveda. Za sve ispitivane osobine primenom metoda najmanjih kvadrata izračunati su osnovni varijaciono-statistički parametri: aritmetička sredina, standardna devijacija, koeficijenti varijacije, standardna greška i interval varijacije.

Negativne fenotipske korelacije između proizvodnje mleka i osobina tipa kretale su se u intervalu od -0.12 (položaj zadnjih nogu sa strane) do - 0.01 (visina krsta i dubina tela), a pozitivne od 0.03 (položaj zadnjih sisa) do 0.23 (centralni ligament). Fenotipske korealacije između procenta mlečne masti i osobina tipa kretale su se u intervalu od -0.08 (pozicija prednjih sisa) do 0.14 (visina krsta).

Negativne genetske korelacije između proizvodnje mleka i osobina tipa varirale su u razmaku od -0.11 (visina zadnjeg vimena) do -0.01 (širina karlice $i$ mlečne karakteristike), a pozitivne od 0.03 (položaj zadnjih nogu otpozadi) do 0.23 (centralni ligament). Genetske korealacije između procenta mlečne masti i osobina tipa kretale su se u intervalu od -0.15 (položaj karlice) do 0.18 (visina krsta). Postojanje informacija o fenotipskim i genetskim korelacijama između osobina mlečnosti i tipa, može imati višestruki značaj u selekciji krava, jer pruža mogućnost odabira grla na više osobina istovremeno. 


\section{Literature}

BULLENKATALOG, Februar 2001., Semex Deutschland.

HARRIS D.L., NEWMAN S. (1994). Breeding for profit: synergism between genetic improvement and livestock production (A review). Journal of Animal Science, 72, 2178-2200.

KOENEN, E.P.C., GROEN, A.F. (1998): Genetic Evaluation of Body Weight of Lactating Holstein Heifers Using Body Measurements and Conformation Traits. J. Dairy Sci. 81(6), 1709-1713.

PANTELIĆ,V. (2004): Fenotipska varijabilnost proizvodnih i reproduktivnih osobina bikovskih majki simentalske rase. Magistarska teza. Poljoprivredni fakultet, Beograd.

PANTELIĆ, V., SKALICKI Z., PETROVIĆ, M.M., LATINOVIĆ, D., ALEKSIĆ, S., MIŠČEVIĆ, B., DUŠICA OSTOJIĆ (2007): Linearno ocenjivanje bikovskih majki simentalske rase. Savremena poljoprivreda 1-2, p. 49-53.

PANTELIĆ, V., SKALICKI, Z., BOGDANOVIĆ, V. , DELIĆ, N., PEJČIĆ , S. (2009): The effect of paragenetic factors on body development of simmental bull dams. Biotechnology in Animal Husbandry, vol. 25, (1-2), 53-59.

PANTELIĆ, V., ALEKSIĆ, S., OSTOJIĆ-ANDRIĆ D., SRETENOVIĆ, LJ., PETROVIĆ, M.M., NOVAKOVIĆ, Ž. (2010a): Linear evaluation of the type of holstein-friesian bull dams. Archiva zootechnica 13:1, p 83-60. Balotesti, Romania. PANTELIĆ, V., SAMOLOVAC, Lj., ALEKSIĆ, S., TRIVUNOVIĆ, S., PETROVIĆ, M., OSTOJIĆ-ANDRIĆ, D., NOVAKOVIĆ, Ž. (2010b): Heritability of type traits in first calving Black and White cows, Archiv fur Tierzucht, Vol 53 (2010), 5, 545-554.

V. PANTELIĆ, D. NIKŠIĆ, S. TRIVUNOVIĆ (2011): Variability and heritability of type traits of Holstein-Friesian bull dams. $3^{\text {rd }}$ International Congress "New Perspectives and Challenges of Sustainable Livestock Production", Belgrade, October $5^{\text {th }}$ to $7^{\text {th }}, 2011$, Biotechnology in Animal Husbandry, Vol. 27 (3), p. 305-315. SMITH, L.A., CASSELL, B.G., PEARSON, R.E. (1998): The Effects of Inbreeding on the Lifetime Performance of Dairy Cattle. J. Dairy Sci. 81(10), 2729-2737.

STOJIĆ, P., ŽIVANOVIĆ LJILJANA, BESKOROVAJNI RADMILA, NIKOLIĆ, R., MARKOVIĆ, N. (2002): Značaj linearne ocene tipa u odgajivačkim programima mlečnih goveda. Biotechnology in Animal Husbandry 18 (5-6) p. 31-35. VAN DORP, T.E., DEKKERS, J.C.M., MARTIN, S.W., NOORDHUIZEN, J.P.T.M. (1998): Genetic Parameters of Health Disorders and Relationships with 305 Day Milk Yield and Conformation traits in Canadian Holstein. J. Dairy Sci. 81(8), 2264-2270. 
VOLlEMA, R. ANT, GROEN, F. Ab. (1997): Genetic Correlations Between Longevity And Conformation Traits In An Upgrading Dairy Cattle Population. J. Dairy Sci. 80(11), 3006-3014.

ŽIVANOVIĆ LJILJANA (2002): Varijabilnost linearno ocenjenih osobina tipa i mlečnosti prvotelki crno-bele rase. Magistarska teza. Poljoprivredni fakultet, Beograd.

WEIGEL, K.A., LAWLOR, J.R., VANRADEN, P.M., WIGGANS, G.R. (1998): Use of Linear Type and Production Data to Supplement Early Predicted Transmitting Abilities for Productive Life. 81(7), 2040-2044.

Received 28 December 2011; accepted for publication 19 January 2012 